\title{
Pengaruh Olahraga Intensitas High dan Intensitas Moderate Dengan Musik terhadap TNF- $\alpha$
}

\author{
Rostandi Alfan, Sugiharto*, Olivia Andiana \\ Universitas Negeri Malang, Jl. Semarang No. 5 Malang, Jawa Timur, Indonesia \\ *Penulis korespondensi, Surel: sugiharto@um.ac.id
}

Paper received: 23-7-2021; revised: 13-8-2021; accepted: 20-8-2021

\begin{abstract}
High concentrations of tumor necrosis factor- $\alpha$ (TNF- $\alpha$ ) can lead to insulin resistance. Exercise has been shown to improve the body's physiology. The purpose of this study was to compare the expression of TNF- $\alpha$ in high, moderate, and moderate intensity exercise with listening to music. This research is an experimental laboratory study, with a total sample of 45 men aged 19-23 years who were divided into 3 groups, namely the high, moderate, and moderate intensity exercise group with music. Analysis of blood sample data was then processed using the Special Science Statistical Package (SPSS) computer program. The results of data analysis showed that high intensity had no effect on TNF- $\alpha$ (P is 0.218). Moderate intensity exercise did not result in a significant decrease in TNF- $\alpha$ levels ( $P$ is 0.08). Moderate intensity exercise with music had a significant effect on decreasing TNF- $\alpha$ levels ( $P$ is 0.028 ). From these data, it shows that moderate exercise by listening to music can reduce TNF$\alpha$ levels.
\end{abstract}

Keywords: moderate exercise; high exercise; music; TNF- $\alpha$

\begin{abstract}
Abstrak
Konsentrasi Tumor necrosis factor- $\alpha$ (TNF- $\alpha$ ) yang tinggi dapat mengakibatkan resistensi insulin. Olahraga terbukti dapat memperbaiki kondisi fisiologi tubuh. Tujuan dari penelitian ini yaitu membandingkan ekspresi TNF- $\alpha$ pada olahraga intensitas high, moderate, dan moderate dengan mendengar-kan musik. Penelitian ini adalah penelitian experimental laboratories, dengan jumlah sampel 45 pria berumur 19-23 tahun yang dibagi menjadi 3 kelompok, yaitu kelompok olahraga intensitas high, moderate, dan moderate dengan musik. Data analisis sampel darah kemudian diolah menggunakan program komputer Statistical Package of Special Science (SPSS). Hasil analisis data menunjukkan bahwa, olahraga intensitas high tidak berpengaruh terhadap TNF- $\alpha$ (P adalah 0,218). Olahraga intensitas moderate tidak mengakibatkan penurunan yang signifikan pada kadar TNF- $\alpha$ (P adalah 0,08). Olahraga intensitas moderate dengan musik, berpengaruh secara signifikan terhadap penurunan kadar TNF- $\alpha$ (P adalah 0,028). Dari data tersebut menunjukkan bahwa, olahraga intensitas moderate dengan mendengarkan musik, dapat menurunkan kadar TNF- $\alpha$.
\end{abstract}

Kata kunci: olahraga moderat; olahraga high; musik, TNF- $\alpha$

\section{Pendahuluan}

Tumor necrosis factor- $\alpha$ (TNF- $\alpha$ ) memiliki dua peran di dalam tubuh, yaitu dapat bermanfaat dan juga berbahaya bagi tubuh (Aggarwal, 2003). Namun menurut Martin, dkk (2019), konsentrasi TNF- $\alpha$ yang melebihi ambang normal dapat mengakibatkan resistensi insulin. Resistensi insulin merusak kemampuan sel otot untuk mengambil dan menyimpan glukosa dan trigliserida, menghasilkan kadar glukosa dan trigliserida yang tinggi yang bersirkulasi dalam darah (Misra dkk, 2018). Resistensi insulin adalah faktor penentu dalam patofisiologi diabetes mellitus tipe 2 (DM2) (Kumar dkk, 2018). Menurut data Riskesdas (2018), sekitar 8,5\% masyarakat Indonesia di atas usia 15 tahun mengalami (DM2). DM2 biasanya terkait dengan adipositas viseral, intoleransi glukosa, hipertensi, dislipidemia, disfungsi endotel dan peningkatan kadar penanda inflamasi (Gutch dkk, 2015). Konsentrasi 
TNF- $\alpha$ yang tinggi, juga berhubungan dengan terjadinya kematian sel, penyakit kardiovaskuler, inflamasi (Golbidi \& Laher, 2014), dan tumorigenesis (Aggarwal, 2003).

Kadar TNF- $\alpha$ akan meningkat akibat dari kurangnya olahraga. Olahraga dapat digunakan secara preventif atau juga sebagai pengobatan penyakit seperti obesitas, penyakit jantung, stroke, diabetes mellitus tipe 2, dan kanker tertentu (Barker \& Sarah, 2019). Jika olahraga harian selama 30 menit tidak terpenuhi, maka mampu meningkatkan risiko banyak penyakit atau kondisi kronis, salah satunya adalah obesitas (Thyfault \& Frank, 2011). Pada individu yang obesitas, macrophage-infiltrated lemak viseral adalah tempat utama produksi TNF- $\alpha$ (Karine dkk, 2014). TNF- $\alpha$ dapat menginduksi resistensi insulin dengan menghambat aktivasi insulin receptor substrate (IRS) -1 (Hotamisligil dkk, 1996) dan dengan meningkatkan plasma asam lemak bebas melalui stimulasi lipolisis jaringan adiposa (Green, 2014). Selanjutnya, dalam kultur sel, TNF- $\alpha$ merangsang produksi diasilgliserol (DAG) dan ceramide (Schutze dkk, 2011) yang telah terlibat dalam patogenesis resistensi insulin otot rangka (Chunli, 2002). Resistensi insulin pada individu menyebabkan kondisi hiperinsulinemia. Menurut penelitian Park dkk (2013), kadar insulin yang tinggi berkaitan dengan terjadinya hipertensi, pengamatan selama 4 tahun menunjukkan bahwa pada grup dengan usia lanjut, prevalensi hipertensi lebih tinggi dibandingkan grup dengan usia muda. Ketidakaktifan fisik dan obesitas juga meningkatkan resiko berkembangnya sel kanker tertentu, seperti kanker usus besar, payudara, dan endometrium (Eickmeyer dkk, 2012).

Terdapat beberapa perbedaan hasil penelitian tentang efek olahraga terhadap tingkat TNF- $\alpha$ pada individu yang sehat maupun individu yang diabet (Llyod dkk, 2016). Menurut penelitian Chadorneshin dkk (2019), kadar TNF- $\alpha$ tidak turun secara signifikan setelah diberi High Intensity Interval Training (HIIT). Kadar TNF- $\alpha$ juga tidak ditemukan perubahan, setelah melakukan 6 sesi HIIT selama 2 minggu (Leggate dkk, 2012). Sedangkan menurut penelitian Monzillo dkk (2003), kadar TNF- $\alpha$ cenderung menurun, setelah intervensi dengan aktivitas fisik dan diet. Hal senada juga dikemukakan oleh Jung dkk (2008), bahwa kadar TNF- $\alpha$ secara signifikan turun seiring dengan penurunan berat badan, setelah intervensi dengan diet, medikasi, dan olahraga pada 37 pria obesitas setelah 12 minggu. Beberapa penelitian yang sudah dilakukan menunjukkan perbedaan ekspresi TNF- $\alpha$ pada beberapa jenis kelamin individu dan jenis Sindrom Metabolik (SM) yang diderita, akibat dari jenis intervensi yang diberikan. Namun, belum ada yang menjelaskan bagaimana ekspresi TNF- $\alpha$ dengan intervensi olahraga intensitas high, moderate, dan moderate dengan musik.

\section{Metode}

Penelitian ini adalah penelitian experimental laboratories. Adapun ranca-ngan penelitian yang digunakan adalah Randomized Pretest-Posttest Comparison Group Design. Populasi dalam penelitian ini adalah pria dengan usia 19-23 tahun berjumlah 81 orang. Penentuan sampel dalam penelitian menggunakan teknik matched subject ordinal pairing, mengurutkan hasil bleep test dari peringkat pertama sampai dengan yang terakhir (peringkat ke-45), membagi data menjadi tiga kelompok penelitian, yaitu perlakuan dengan olahraga intensitas high, olahraga intensitas moderate, dan olahraga intensitas moderate dengan mendengarkan musik. 


\subsection{Pelaksanaan Pengambilan Data}

\subsubsection{Sebelum Perlakuan}

(1) Memberikan arahan kepada sampel penelitian mengenai batasan tidur malam, aktifitas fisik yang dilakukan 1 hari sebelum perlakuan dan pengambilan data. (2) Melakukan pemeriksaan kesehatan dan fisik sampel penelitian, dilakukan oleh petugas kesehatan atau dokter. (3) Sebelum melakukan olahraga intensitas moderate dan high dilakukan pemanasan di atas treadmill selama 5 menit.

\subsubsection{Perlakuan}

Sampel melakukan olahraga berlari di atas treadmill sesuai kelompok intensitas. Intensitas moderate berlari di atas treadmill dengan kemampuan 70-75 \% Heart Rate Maximum, sedangkan intensitas high yaitu setara dengan kemampuan 80-85\% Heart Rate Maximum selama 25 menit.

\subsubsection{Setelah Perlakuan}

(1) Setelah perlakuan selama 25 menit sesuai dengan kelompok intensitas, sampel melakukan cooling down selama 5 menit. (2) Setelah melakukan cooling down sampel beristirahat, kemudian proses pengambilan darah sebanyak $10 \mathrm{cc}$ oleh tenaga kesehatan dilakukan. (3) Pemeriksaan kadar TNF- $\alpha$ menggunakan metode ELISA.

\subsection{Analisis Data}

Setelah hasil diketahui selanjutnya perlu dilakukan analisis, adapun ketentuannya dalam menganalisis adalah sebagai berikut: (1) Pengujian data, menggunakan uji statistik deskriptif. (2) Uji normalitas digunakan 5\% (taraf signifikansi/kepercayaan), kemudian melakukan uji homogenitas. (3) Tingkat homogenitas dari suatu kelompok dapat diketahui dengan memilih uji homogenitas varian, dan menggunakan taraf signifikansi 5\%. (4) Untuk mengetahui pengaruh olahraga moderate, high, dan moderate musik terhadap peradangan pada Mahasiswa Putra Fakultas Ilmu Keolahragaan Universitas Negeri Malang peneliti menggunakan uji statistik anova, sedangkan hipotesis diuji berdasarkan probabilitas: Jika Sig.< 0.05, maka Ho = ditolak dan $\mathrm{Hi}=$ diterima. Jika Sig. $>0.05$, maka Ho = diterima dan $\mathrm{Hi}=$ ditolak. Semua data diuji dengan analisis statistik anova dengan taraf signifikansi $a=0.05$ dengan langkah-langkah uji normalitas, kemudian sesudah itu menguji homogenitas sebagai syarat untuk uji statistik anova. Pengujian semua data menggunakan aplikasi Statistik Package for Social Science (SPSS 17.0). 


\section{Hasil dan Pembahasan}

Subyek penelitian sejumlah 45 remaja yang dipilih berdasarkan inklusi, disampaikan pada Tabel 1.

Tabel 1. Karakteristik Subjek Penelitian

\begin{tabular}{lccc}
\hline \multicolumn{1}{c}{ Karakteristik Subjek } & \multicolumn{3}{c}{ Kelompok } \\
\cline { 2 - 4 } & A & B & C \\
\hline$\dot{\boldsymbol{V}} \mathrm{O}_{\text {Maks }}(\mathrm{mL} / \mathrm{kg} \cdot \mathrm{min})$ & 41.65 & 41.00 & 40.90 \\
$\mathrm{Umur}(\mathrm{th})$ & 20 & 20 & 21 \\
$\mathrm{BB}(\mathrm{kg})$ & 59 & 60 & 59 \\
$\mathrm{~TB}(\mathrm{~m})$ & 1.66 & 1.70 & 1.70 \\
$\mathrm{IMT}\left(\mathrm{kg} / \mathrm{m}^{2}\right)$ & 21.57 & 22.00 & 21.00 \\
$\mathrm{Hb}(\mathrm{g} / \mathrm{dL})$ & 15.47 & 16.50 & 15.50 \\
$\mathrm{Tekanan}$ Darah $(\mathrm{mlHg})$ & $120 / 80$ & $110 / 80$ & $120 / 80$ \\
Heart Rate $(\mathrm{bpm})$ & 72 & 70 & 69 \\
\hline
\end{tabular}

Keterangan:

A: Kelompok Olahraga Intensitas High

B: Kelompok Olahraga Intensitas Moderate

C: Kelompok Olahraga Intensitas Moderate dengan Musik

\subsection{Uji Statistik Deskriptif}

Data hasil analisis sampel darah dengan parameter TNF- $\alpha$ kemudian diuji statistik deskriptif, meliputi rata-rata (mean), nilai tengah (median), dan standar deviasi (SD) dapat dilihat pada Tabel 2 .

Berdasarkan hasil uji statistik deskriptif (Tabel 2), kelompok A tidak menunjukkan penurunan dari hasil intervensi yang telah diberikan (pre-test $=127,44$ dan post-test $=158,93$ ), sedangkan pada 2 kelompok lainnya menunjukkan kecenderungan menurun, oleh sebab itu, akan dilakukan uji beda dalam kelompok dan uji beda antar kelompok. Masing-masing dari dua jenis uji beda tersebut, harus melewati tahap uji normalitas, uji homogenitas, dan yang terakhir adalah uji ANOVA.

Tabel 2. Uji Statistik Deskriptif

\begin{tabular}{cccccccc}
\hline \multirow{2}{*}{ Kelompok } & \multirow{2}{*}{ N } & \multicolumn{3}{c}{ Pre } & \multicolumn{3}{c}{ Post } \\
\cline { 3 - 7 } & & Mean & Median & SD & Mean & Median & SD \\
\hline A & 15 & 127,44 & 110,33 & 74,55 & 158,93 & 127,00 & 69,58 \\
B & 15 & 135,66 & 123.67 & 37,66 & 110,66 & 98,33 & 37,62 \\
C & 15 & 133,22 & 123,67 & 39,89 & 98,95 & 93,33 & 41,20 \\
\hline
\end{tabular}

Keterangan:

A: Kelompok Olahraga Intensitas High

B: Kelompok Olahraga Intensitas Moderate

C: Kelompok Olahraga Intensitas Moderate dengan Musik

$\mathrm{N}$ : Jumlah sampel

\subsection{Uji Beda dalam Kelompok}

Uji beda dalam kelompok, dilakukan untuk menguji nilai signifikansi perbedaan ratarata saat pre-test dan rata-rata saat post-test. Pengujian melewati tahap uji normalitas, uji 
homogenitas, dan kemudian uji ANOVA. Dalam penelitian ini terdapat tiga kelompok penelitian, jadi hasil pre-test dan post-test dari ketiga kelompok tersebut, akan diuji nilai signifikansinya dengan melihat nilai rata-rata masing-masing kelompok.

\subsubsection{Uji Normalitas}

Uji normalitas dilakukan untuk melihat tingkat normalitas sebuah data yang ada. Pengambilan keputusan berdasarkan nilai signifikansi hasil uji data menggunakan aplikasi SPSS. Jika nilai signifikansi $>0,05$, maka data dikatakan berdistribusi normal, dan jika nilai signifikansi $<0,05$, maka data dikatakan berdistribusi tidak normal. Hasil uji normalitas disajikan pada Tabel 3.

Berdasarkan uji normalitas Kolmogorov-Smirnov, data pada semua kelompok berdistribusi normal $(\mathrm{P}>0,05)$, baik saat pre-test maupun post-test.

Tabel 3. Uji Normalitas

\begin{tabular}{ccccc}
\hline \multirow{2}{*}{ Kelompok } & \multicolumn{3}{c}{ Kolmogorov-Smirnov } \\
\cline { 2 - 5 } & \multicolumn{2}{c}{ Statistik } & \multicolumn{2}{c}{ Signifikansi } \\
\cline { 2 - 5 } & Pre & Post & Pre & Post \\
\hline A & 0,173 & 0,21 & 0,20 & 0,73 \\
B & 0,158 & 0,162 & 0,20 & 0,20 \\
C & 0,196 & 0,157 & 0,12 & 0,20 \\
\hline
\end{tabular}

Keterangan:

A: Kelompok Olahraga Intensitas High

B: Kelompok Olahraga Intensitas Moderate

C: Kelompok Olahraga Intensitas Moderate dengan Musik

\subsubsection{Uji Homogenitas}

Uji homogenitas dilakukan untuk mengetahui dua kelompok data sampel atau lebih, berasal dari populasi yang memiliki varian sama (homogen). Pengujian ini merupakan prasyarat untuk melakukan uji ANOVA (Analysis of Variance). Pengambilan keputusan berdasarkan nilai signifikansi hasil uji data menggunakan aplikasi SPSS. Jika nilai signifikansi $>0,05$, maka distribusi data homogen, dan jika nilai signifikansi $<0,05$, maka distribusi data tidak homogen. Hasil uji homogenitas disajikan pada Tabel 4.

Hasil uji homogenitas menunjukan bahwa, data homogen pada tiap kelompok perlakuan $(\mathrm{P}>0,05)$. Data yang homogen dapat dilanjutkan ke pengujian selanjutnya, yaitu uji ANOVA.

Tabel 4. Uji Homogenitas

Keterangan:

\begin{tabular}{ccrcc}
\hline Kelompok & Levene Stat. & df1 & df2 & Signifikansi \\
\hline A & 0,055 & 1 & 28 & 0,967 \\
B & 1,902 & 1 & 28 & 0,996 \\
C & 0,831 & 1 & 28 & 0,857 \\
\hline
\end{tabular}

A: Kelompok Olahraga Intensitas High

B: Kelompok Olahraga Intensitas Moderate

C: Kelompok Olahraga Intensitas Moderate dengan Musik 


\subsubsection{Uji ANOVA}

Uji ANOVA dilakukan untuk menguji hipotesis penelitian dengan menilai perbedaan rerata antar kelompok. Jika nilai signifikansi $>0,05$, berarti tidak ada pengaruh akibat dari perlakuan, dan jika nilai signifikansi $<0,05$, berarti terdapat pengaruh akibat dari perlakuan yang diberikan. Hasil uji ANOVA disajikan pada tabel 5.

Berdasarkan pengujian ANOVA pada ketiga kelompok perlakuan, menunjukkan bahwa terdapat pengaruh yang signifikan pada kelompok dengan perlakuan olahraga intensitas moderate dengan musik (Kelompok $\mathrm{C})(\mathrm{P}<0,05)$, namun tidak terdapat pengaruh pada kelompok dengan perlakuan olahraga intensitas high (Kelompok A) $(\mathrm{P}>0,05)$ dan olahraga intensitas moderate (Kelompok B) $(\mathrm{P}>0,05)$.

Tabel 5. Uji ANOVA

Keterangan:

A: Kelompok Olahraga Intensitas High

B: Kelompok Olahraga Intensitas Moderate

C: Kelompok Olahraga Intensitas Moderate dengan Musik

\subsection{Uji Beda antar Kelompok}

Setelah dilakukannya uji beda dalam kelompok, data penelitian juga dianalisis uji beda antar kelompok, untuk menguji apakah ada perbedaan di antara ketiga kelompok perlakuan, saat pre-test maupun saat post-test. Pengujian dimulai dari uji normalitas, kemudian data diuji homogenitasnya, dan yang terakhir akan diuji ANOVA. Karena pada pengujian data dalam kelompok sudah dilakukan pengujian normalitas ketiga kelompok saat pre-test maupun posttest, maka pengujian data langsung dilanjutkan dengan uji homogenitas, dan ANOVA.

\subsubsection{Uji Homogenitas Data Pre-Test Ketiga Kelompok}

Uji homogenitas dilakukan untuk mengetahui dua kelompok data sampel atau lebih, berasal dari populasi yang memiliki varian sama (homogen). Pengujian ini merupakan prasyarat untuk melakukan uji ANOVA (Analysis of Variance). Pengambilan keputusan berdasarkan nilai signifikansi hasil uji data menggunakan aplikasi SPSS. Jika nilai signifikansi $>0,05$, maka distribusi data homogen, dan jika nilai signifikansi $<0,05$, maka distribusi data tidak homogen. Hasil uji homogenitas disajikan pada Tabel 6.

Hasil uji homogenitas menunjukkan bahwa, data ketiga kelompok pre-test homogen (P $>0,05)$. Data yang homogen dapat dilanjutkan ke uji ANOVA.

Tabel 6. Uji Homogenitas Pre-Test Ketiga Kelompok

\begin{tabular}{cccc}
\hline Levene Statistic & df1 & df2 & Sig. \\
\hline 2.895 & 2 & 42 & .066 \\
\hline
\end{tabular}




\subsubsection{Uji ANOVA Data Pre-Test Ketiga Kelompok}

Uji ANOVA dilakukan untuk melihat apakah ada perbedaan antara data pre-test pada ketiga kelompok. Jika nilai signifikansi $>0,05$, maka tidak ada beda di antara ketiga kelompok perlakuan saat pre-test, dan jika nilai signifikansi $<0,05$, maka ada beda di antara ketiga perlakuan saat pre-test. Hasil uji ANOVA data pre-test ketiga kelompok disajikan pada Tabel 7.

Dari hasil uji ANOVA antara data pre-test pada ketiga kelompok menunjukkan nilai signifikansi 0,911 ( $\mathrm{P}>0,05)$, maka dapat diartikan data di antara ketiga kelompok perlakuan saat pre-test tidak ada beda satu sama lain. Data kemudian dapat diuji lanjutan (Post Hoc Test) menggunakan uji LSD.

Tabel 7. Uji ANOVA Pre-test Ketiga Kelompok

\begin{tabular}{llllll}
\hline & Sum of Squares & $\mathrm{df}$ & Mean Square & $\mathrm{F}$ & Sig. \\
\hline Between Groups & 534.847 & 2 & 267.424 & 0.094 & 0.911 \\
Within Groups & 119970.291 & 42 & 2856.435 & & \\
Total & 120505.138 & 44 & & & \\
\hline
\end{tabular}

\subsubsection{Uji LSD}

Uji LSD dilakukan untuk melihat adakah perbedaan antar kelompok perlakuan. Uji ini hampir sama dengan uji ANOVA, namun lebih rinci menjelaskan perbedaan antar kelompok perlakuan. Jika nilai signifikansi $>0,05$, maka tidak ada beda di antara ketiga kelompok perlakuan saat pre-test, dan jika nilai signifikansi $<0,05$, maka ada beda di antara ketiga perlakuan saat pre-test. Hasil uji LSD pada ketiga kelompok perlakuan dapat dilihat pada Tabel 8.

Dari hasil uji LSD, terlihat bahwa tidak ada perbedaan di antara ketiga kelompok saat pre-test. Terlihat nilai signifikansi ketiga kelompok $>0,05$, maka dapat diambil kesimpulan bahwa, ketiga kelompok saat pre-test tidak terdapat perbedaan.

Tabel 8. Uji LSD pre-test Ketiga Kelompok

\begin{tabular}{ccccccc}
\hline \multirow{2}{*}{ Kelompok } & \multirow{2}{*}{ Kelompok } & $\begin{array}{c}\text { Mean Difference } \\
\text { (I-J) }\end{array}$ & $\begin{array}{c}\text { Std. } \\
\text { Eror }\end{array}$ & Sig. & \multicolumn{2}{c}{ 95\% Confidence Interval } \\
\hline \multirow{2}{*}{ A } & B & -8.22 & 19.52 & .676 & -47.61 & Lower Bound \\
& C & -5.78 & 19.52 & 0.769 & -45.16 & 31.16 \\
& A & 8.22 & 19.52 & 0.676 & -31.16 & 47.61 \\
B & C & 2.45 & 19.52 & 0.901 & -36.94 & 41.83 \\
& A & 5.78 & 19.52 & 0.769 & -33.61 & 45.16 \\
C & B & -2.45 & 19.52 & 0.901 & -41.83 & 36.94 \\
\hline
\end{tabular}

Keterangan:

A: Kelompok Olahraga Intensitas High

B: Kelompok Olahraga Intensitas Moderate

C: Kelompok Olahraga Intensitas Moderate dengan Musik 


\subsubsection{Uji Homogenitas Data Post-Test Ketiga Kelompok}

Uji homogenitas dilakukan untuk mengetahui dua kelompok data sampel atau lebih, berasal dari populasi yang memiliki varian sama (homogen). Pengujian ini merupakan prasyarat untuk melakukan uji ANOVA (Analysis of Variance). Pengambilan keputusan berdasarkan nilai signifikansi hasil uji data menggunakan aplikasi SPSS. Jika nilai signifikansi $>0,05$, maka distribusi data homogen, dan jika nilai signifikansi $<0,05$, maka distribusi data tidak homogen. Hasil uji homogenitas disajikan pada Tabel 9.

Hasil uji homogenitas menunjukkan bahwa, data ketiga kelompok post-test homogen (P $>0,05)$. Data yang homogen dapat dilanjutkan ke uji ANOVA.

\section{Tabel 9. Uji Homogenitas Post-Test Ketiga Kelompok}

\begin{tabular}{llll}
\hline Levene Statistic & df1 & df2 & Sig. \\
\hline 3.739 & 2 & 42 & .062 \\
\hline
\end{tabular}

\subsubsection{Uji ANOVA Data Post-Test Ketiga Kelompok}

Uji ANOVA dilakukan untuk melihat apakah ada perbedaan antara data post-tes pada ketiga kelompok. Jika nilai signifikansi $>0,05$, maka tidak ada beda di antara ketiga kelompok perlakuan saat post-test, dan jika nilai signifikansi $<0,05$, maka ada beda di antara ketiga perlakuan saat post-test. Hasil uji ANOVA data post-test ketiga kelompok disajikan pada Tabel 10.

Dari hasil uji ANOVA antara data post-tes pada ketiga kelompok menunjukkan nilai signifikansi 0,006 $(\mathrm{P}<0,05)$, maka dapat diartikan data di antara ketiga kelompok perlakuan saat post-test berbeda satu sama lain. Data kemudian dapat diuji lanjutan (Post Hoc Test) menggunakan uji LSD.

Tabel 10. Uji ANOVA Data Post-test Ketiga Kelompok

\begin{tabular}{llllll}
\hline & Sum of Squares & df & Mean Square & F & Sig. \\
\hline Between Groups & 30321.178 & 2 & 15160.589 & 5.717 & 0.006 \\
Within Groups & 111376.719 & 42 & 2651.827 & & \\
Total & 141697.898 & 44 & & & \\
\hline
\end{tabular}

\subsubsection{Uji LSD}

Uji LSD dilakukan untuk melihat adakah perbedaan antar kelompok perlakuan. Uji ini hampir sama dengan uji ANOVA, namun lebih rinci menjelaskan perbedaan antar kelompok perlakuan. Jika nilai signifikansi $>0,05$, maka tidak ada beda di antara ketiga kelompok perlakuan saat post-test, dan jika nilai signifikansi $<0,05$, maka ada beda di antara ketiga perlakuan saat post-test. Hasil uji LSD pada ketiga kelompok perlakuan dapat dilihat pada Tabel 11.

Dari hasil uji LSD terlihat perbedaan pada kelompok Olahraga Intensitas High - Olahraga Intensitas Moderate $(\mathrm{P}<0,05)$, kelompok Olahraga Intensitas High - Olahraga Intensitas Moderate dengan Musik $(\mathrm{P}<0,05)$, kelompok Olahraga Intensitas Moderate - Olahraga 
Intensitas High $(\mathrm{P}<0,05)$, dan kelompok Olahraga Intensitas Moderate dengan Musik Olahraga Intensitas High $(\mathrm{P}<0,05)$. Namun tidak ada perbedaan pada kelompok Olahraga Intensitas Moderate - Olahraga Intensitas Moderate dengan Musik $(\mathrm{P}>0,05)$ dan kelompok Olahraga Intensitas Moderate dengan Musik - Olahraga Intensitas Moderate $(\mathrm{P}>0,05)$.

Tabel 11. Uji LSD post-test Ketiga Kelompok

\begin{tabular}{lllllll}
\hline \multirow{2}{*}{ Kelompok } & \multirow{2}{*}{ Kelompok } & $\begin{array}{c}\text { Mean } \\
\text { Difference (I-J) }\end{array}$ & $\begin{array}{c}\text { Std. } \\
\text { Error }\end{array}$ & Sig. & \multicolumn{2}{c}{$\begin{array}{c}\text { 95\% Confidence Interval } \\
\text { Lower Bound }\end{array}$} \\
& & Upper Bound & B \\
\hline \multirow{2}{*}{ A } & B & 48.26 & 18.8 & .014 & 10.32 & 86.21 \\
& C & 59.97 & 18.8 & .003 & 22.03 & 97.92 \\
B & A & -48.26 & 18.8 & .014 & -86.21 & -10.32 \\
& C & 11.71 & 18.8 & .537 & -26.23 & 49.65 \\
C & A & -59.97 & 18.8 & .003 & -97.92 & -22.03 \\
& B & -11.71 & 18.8 & .537 & -49.65 & 26.23 \\
\hline
\end{tabular}

Keterangan:

A: Kelompok Olahraga Intensitas High

B: Kelompok Olahraga Intensitas Moderate

C: Kelompok Olahraga Intensitas Moderate dengan Musik

Uji beda antar kelompok dilakukan untuk menguji ataupun melihat apakah ada perbedaan di antara ketiga kelompok saat pre-test dan post-test. Pengujian dimulai dari uji normalitas, homogenitas, uji ANOVA, dan kemudian uji LSD. Karena uji normalitas sudah dilakukan saat uji beda dalam kelompok, maka pengujian data dapat dilanjutkan ke uji homogenitas. Terlihat pada Tabel 4.6, data homogen $(\mathrm{P}>0,05)$, dan juga pada Tabel 9 , data homogen $(\mathrm{P}>0,05)$. Data yang homogen dapat dilanjutkan ke uji ANOVA, dan terlihat pada Tabel 4.7, nilai signifikansi uji ANOVA > 0,05. Maka dapat disimpulkan, bahwa tidak terdapat perbedaan di antara ketiga kelompok perlakuan. Sedangkan pada Tabel 10, nilai signifikansi uji ANOVA $<0,05$, maka dapat disimpulkan, bahwa terdapat perbedaan di antara ketiga perlakuan olahraga tersebut. Pada uji LSD juga terlihat demikian, terlihat pada Tabel 4.8, ketiga kelompok menunjukkan nilai signifikansi $>0,05$, yang artinya tidak ada perbedaan di antara ketiga kelompok. Sedangkan pada Tabel 11, terlihat perbedaan pada kelompok Olahraga Intensitas High - Olahraga Intensitas Moderate $(\mathrm{P}<0,05)$, kelompok Olahraga Intensitas High Olahraga Intensitas Moderate dengan Musik $(\mathrm{P}<0,05)$, kelompok Olahraga Intensitas Moderate - Olahraga Intensitas High $(\mathrm{P}<0,05)$, dan kelompok Olahraga Intensitas Moderate dengan Musik - Olahraga Intensitas High $(\mathrm{P}<0,05)$. Namun tidak ada perbedaan pada kelompok Olahraga Intensitas Moderate - Olahraga Intensitas Moderate dengan Musik $(\mathrm{P}>0,05)$ dan kelompok Olahraga Intensitas Moderate dengan Musik - Olahraga Intensitas Moderate (P > $0,05)$.

Ekspresi TNF- $\alpha$ tidak menunjukkan penurunan, bahkan terjadi kenaikkan level, dengan pemberian perlakuan olahraga lari di atas treadmill pada sampel dengan intensitas high (8085\% Heart Rate Maximum). Hasil uji ANOVA menunjukkan bahwa tidak ada pengaruh penurunan ekspresi TNF- $\alpha$ dari pemberian perlakuan olahraga intensitas high pada sampel (P $>0,05, \mathrm{P}=0,218$ ). Kenaikan rata-rata kadar TNF- $\alpha$ dari pre-tes yaitu sebesar $127,44 \mathrm{pg} / \mathrm{ml}$ menjadi $158,93 \mathrm{pg} / \mathrm{ml}$ saat post-tes. Kenaikan kadar TNF- $\alpha$ mengakibatkan beberapa kondisi patologis pada tubuh, seperti resistensi insulin, diabetes mellitus tipe 2, penyakit paru obstruktif kronis dan kardiovaskular, kanker usus besar dan payudara. Namun, untuk meningkatkan performa olahraga memang harus melakukan ataupun melalui olahraga intensitas tinggi. Penurunan performa dan kelelahan akut akan terjadi, yang diakibatkan oleh 
olahraga intensitas tinggi, namun yang perlu diperhatikan adalah adaptasi terhadap latihan yang optimal, tergantung pada periode pemulihan yang memadai (Halson dkk, 2003).

Beberapa penelitian yang lain menyatakan bahwa kadar TNF- $\alpha$ tidak mengalami perubahan setelah berolahraga (Saghizadeh dkk, 1996), bahkan terjadi kenaikkan segera setelah akhir latihan atau nanti setelah masa pemulihan (Moldoveanu dkk, 2001). Olahraga intensitas tinggi dapat menyebabkan inflamasi di dalam otot yang dapat ditelusuri ke pelepasan mitokondria dan kemudian menginduksi reactive oxygen species (ROS) (Allen dkk, 2015). Akumulasi semacam itu menghasilkan banyak pengaruh hilir di dalam miosit (sel otot) dan jaringan sekitarnya. Pembuatan ROS yang diinduksi oleh olahraga dapat memulai serangkaian peristiwa pensinyalan intraseluler yang sensitif terhadap redoks. Misalnya, NFkappaB (NFkB) dan activator protein-1 (AP-1), keduanya merupakan faktor transkripsi potensial yang terlibat dalam peradangan, diaktifkan setelah latihan yang melelahkan (Hollander dkk, 2001). Hubungan antara ROS yang diinduksi oleh olahraga dan faktor-faktor transkripsi ini menjadi jelas ketika penghambat xantin oksidase dan allopurinol berpengaruh, cukup untuk melemahkan pengikatan NFkB pada otot rangka (Gomez dkk, 2005). Protein lain yang terkait dengan proses inflamasi setelah olahraga termasuk keluarga protein kinase yang diaktifkan oleh mitogen-activated protein kinases (MAPK), yang bersama-sama memulai proses yang penting untuk peradangan, adaptasi otot, dan kontrol metabolik di dalam otot rangka (Kramer dan Goodyear, 2007). Menariknya, keluarga MAPK (p38, erk 1/2, jnk, dan erk 5) diaktifkan secara berbeda tergantung pada modalitas latihan (Gomez dkk, 2005). Misalnya, tampaknya latihan konsentris menginduksi fosforilasi MAPK erk1/2 tetapi tidak MAPK p38. Di sisi lain, latihan eksentrik dapat secara bersamaan mengaktifkan kedua kinase, yang mengarah ke peristiwa pensinyalan hilir yang terpisah (Wretman dkk, 2001).

Jalur MAPK yang diaktifkan secara diferensial menyoroti kompleksitas jalur otot dan proses inflamasi selanjutnya yang terjadi setelah latihan. Efek pleiotropik ini sangat bergantung pada mode kontraksi otot (eksentrik dan konsentris) serta intensitas, durasi, dan kebaruan dari tugas olahraga. Selain produksi ROS, faktor-faktor ini juga berkontribusi pada tingkat kerusakan otot setelah berolahraga. Pengetahuan saat ini menunjukkan bahwa kerusakan otot dimulai ketika miofibril diregangkan selama kontraksi (Niess dan Simon, 2007). Respons langsung terhadap cedera otot adalah pelepasan berbagai pola molekuler terkait kerusakan (DAMPs), yang dilepaskan ke lingkungan ekstraseluler sebagai respons terhadap trauma (Kharraz dkk, 2013). Hasilnya adalah gangguan integritas di dalam miosit, yang meliputi gangguan pada retikulum sarkoplasma, tubulus transversal, dan protein myofibrillar (Proske \& Morgan, 2005). Kerusakan yang berlebihan pada area ini dapat menyebabkan perubahan homeostasis kalsium dan kejadian proteolitik atau inflamasi selanjutnya (Niess dan Simon, 2007). Kerusakan pada protein dan membran di dalam area ini juga mengakibatkan peningkatan agen inflamasi seperti prostaglandin, substansi $P$, dan sitokin inflamasi, yang mendorong migrasi efektor imun bawaan (yaitu makrofag dan neutrofil) ke area yang rusak (Proske \& Allen, 2005).

Pemberian perlakuan olahraga lari di atas treadmill pada sampel dengan intensitas moderate (70-80\% Heart Rate Maximum), tidak terjadi penurunan yang signifikan ( $\mathrm{P}>0,05, \mathrm{P}$ $=0,08$ ) pada ekspresi TNF- $\alpha$ setelah data diuji dengan ANOVA. Namun, terlihat perubahan ratarata (mean) hasil pemeriksaan darah pada sampel dengan parameter TNF- $\alpha$ saat pre-test dan post-test, yaitu dari 135,67 pg/ml menjadi 110,67 pg/ml. Hal senada juga dikemukakan oleh Monzillo dkk (2003), bahwa kadar TNF- $\alpha$ cenderung menurun, setelah intervensi dengan 
aktivitas fisik dan diet. Dari hasil tersebut menguatkan bahwa olahraga intensitas moderate dapat memperbaiki beberapa kondisi tubuh. Gabriel and Kindermann (1997) mengemukakan bahwa olahraga intensitas moderat dapat meningkatkan sistem kekebalan tubuh. Beberapa penelitian yang lain juga menunjukkan bahwa olahraga intensitas moderate meningkatkan pelepasan sitokin proinflamasi dan anti inflamasi dan menghasilkan katekolamin, corticotropin-releasing hormone (CRH), adrenocorticotropic hormone (ACTH) dan pelepasan kortisol (Petersen \& Pedersen, 2005).

Kadar penanda inflamasi dalam peredaran darah, salah satunya yaitu Tumor Necrosis Factor- $\alpha$ (TNF- $\alpha$ ), juga diketahui meningkat terkait dengan penuaan, dan karenanya sering diukur dalam penelitian. dan diagnosis (Sjoholm and Nystrom, 2006). Olahraga berperan sebagai obat yang aman untuk mengurangi peradangan dan penuaan sel. Latihan aerobik menurunkan produksi sitokin pro-inflamasi, aterogenik IL- $1 \beta$, TNF- $\alpha$, interferon gamma (INF$\gamma)$ dan C-reaktif protein dan meningkatkan produksi anti-inflamasi, sitokin pelindung arteri, IL-10 (Goldhammer dkk, 2005). Olahraga dengan intensitas moderate menurut Cechella dkk (2014), menginduksi adaptasi positif dalam memodulasi kadar sitokin, mengurangi sitokin proinflamasi dan meningkatkan IL-10, dan juga menginduksi sitokin anti inflamasi, tanpa menyebabkan stres oksidatif pada otot dan hati. Olahraga jangka panjang intensitas moderate juga menyebabkan penurunan besar sitokin pro-inflamasi pada individu obesitas dan nonobesitas (Boghrabadi dkk, 2012).

Ekspresi TNF- $\alpha$ menunjukkan penurunan yang signifikan, setelah diberikan perlakuan olahraga intensitas moderat (70-80\% Heart Rate Maximum) di atas treadmill dengan musik. Hasil uji ANOVA menunjukkan bahwa terdapat penurunan yang signifikan pada ekspresi TNF$\alpha$ dari pemberian perlakuan olahraga intensitas moderat dengan musik terhadap sampel $(\mathrm{P}<$ $0,05, \mathrm{P}=0,028)$. Data tersebut menunjukkan bahwa berolahraga dengan mendengarkan musik, dapat menurunkan stres fisiologis, atau bahkan stres psikologis. Stres mempengaruhi Hypothalamus-Pituitary-Adrenal axis (HPA-axis) (Clark \& Mach, 2016) dan kemudian mengeluarkan Adrenocorticotropin Hormone (ACTH) (Powers and Howley, 2015). Sekresi ACTH merangsang sekresi hormon kortisol (Usui dkk, 2011). Kortisol diketahui sebagai penyebab sekresi sitokin pro-inflamasi, seperti TNF- $\alpha$. Musik berperan sebagai anti inflamasi, anti nyeri, serta lebih melemaskan otot, dan terhindar dari kerusakan akibat efek endorphin (Sugiharto dkk, 2017). Karena musik menyebabkan sekresi endorphin, sedangkan endorphin adalah hormon yang tidak hanya menyebabkan kenikmatan dan relaksasi, tetapi juga hormon anti nyeri atau sistem opioid (Nandhra, 2000).

Selama latihan, musik biasanya digunakan untuk tujuan motivasi, untuk mengimbangi kelelahan emosional dan fisik, dan untuk meningkatkan kinerja. Penelitian terbaru menyiratkan bukti fisiologis untuk peran musik dalam meningkatkan kinerja olahraga, memperbaiki profil lipid, dan memfasilitasi pemulihan pasca latihan (Yamasaki dkk, 2012). Brownley dkk (1995) menyelidiki dampak fisiologis dari tidak mendengarkan musik, musik bertempo cepat, dan musik penenang untuk pelari terlatih dan tidak terlatih selama latihan dengan intensitas yang berbeda-beda. Dalam kondisi latihan intensitas tinggi, pelari yang mendengarkan musik cepat memiliki kadar kortisol plasma yang lebih tinggi (Brownley dkk, 1995). Mengingat peran kortisol dalam mendorong katabolisme substrat energi di otot, adiposa, dan jaringan ikat, ini menunjukkan potensi manfaat metabolik untuk penggunaan musik yang ceria selama latihan (Yamasaki dkk, 2012). Menariknya, musik memiliki efek psikologis yang berbeda tergantung pada tingkat pelatihan; pelari yang tidak terlatih 
melaporkan pengaruh psikologis yang lebih positif dari musik cepat selama latihan intensitas tinggi dan rendah dibandingkan dengan pelari terlatih yang mengalami perasaan paling negatif saat mendengarkan musik cepat (Brownley dkk, 1995).

Oleh karena itu, untuk mencapai manfaat musik yang maksimal selama berolahraga mungkin memerlukan kalibrasi jenis musik yang digunakan dan pertimbangan tingkat kebugaran individu (Yamasaki dkk, 2012). Dalam penelitian ini menunjukkan dampak positif dari musik terhadap penurunan kadar proinflamasi, TNF- $\alpha$. Kombinasi antara olahraga intensitas moderate dan musik menunjukkan penurunan kadar TNF- $\alpha$. Meskipun minim dari penelitian sebelumnya, atau bahkan belum ada yang meneliti akan hal ini, diharapkan hasil dari penelitian ini dapat menjadi dasar penelitian selanjutnya.

\section{Simpulan}

Berdasarkan hasil penelitian tersebut, mengenai pengaruh olahraga terhadap kadar TNF- $\alpha$ di dalam tubuh, maka dapat disimpulkan, sebagai berikut: (1)Olahraga intensitas high meningkatkan kadar TNF- $\alpha(\mathrm{P}>0,05)$, (2) Olahraga intensitas moderate menurunkan kadar TNF- $\alpha$, namun tidak signifikan (P > 0,05), (3) Olahraga intensitas moderate dengan mendengarkan musik menurunkan kadar TNF- $\alpha$ secara signifikan $(\mathrm{P}<0,05)$, (4) Terdapat perbedaan rata-rata TNF- $\alpha$ pada ketiga kelompok saat post-tes $(\mathrm{P}<0,05)$.

\section{Daftar Rujukan}

Aggarwal, B. B. (2003). Signalling pathways of the TNF superfamily: a double-edged sword. Nature reviews immunology, 3(9), 745-756.

Allen, J., Sun, Y., \& Woods, J. A. (2015). Exercise and the regulation of inflammatory responses. Progress in molecular biology and translational science, 135, 337-354.

Barker, K., \& Eickmeyer, S. (2020). Therapeutic exercise. Med Clin North Am, 104(2), 189-198.

Boghrabadi, V., Hejazi, S. M., Gonabadi, A. H., Sanian, H., \& Aminian, F. (2012). Effects of moderate-intensity exercise on serum proinflammatory cytokine levels in obese and non-obese men. Life Sci J, 9(3), 25292532.

Brownley, K. A., McMurray, R. G., \& Hackney, A. C. (1995). Effects of music on physiological and affective responses to graded treadmill exercise in trained and untrained runners. International journal of psychophysiology, 19(3), 193-201.

Cechella, J. L., Leite, M. R., Dobrachinski, F., Da Rocha, J. T., Carvalho, N. R., Duarte, M. M., ... \& Zeni, G. (2014). Moderate swimming exercise and caffeine supplementation reduce the levels of inflammatory cytokines without causing oxidative stress in tissues of middle-aged rats. Amino acids, 46(5), 11871195.

Chadorneshin, H. T., Cheragh-Birjandi, S., Goodarzy, S., \& Ahmadabadi, F. (2019). The impact of high intensity interval training on serum chemerin, tumor necrosis factor-alpha and insulin resistance in overweight women. Obesity medicine, 14, 100101.

Clark, A., \& Mach, N. (2016). Exercise-induced stress behavior, gut-microbiota-brain axis and diet: a systematic review for athletes. Journal of the International Society of Sports Nutrition, 13(1), 1-21.

Clément, K., Viguerie, N., Poitou, C., Carette, C., Pelloux, V., Curat, C. A., ... \& Langin, D. (2004). Weight loss regulates inflammation-related genes in white adipose tissue of obese subjects. The FASEB Journal, 18(14), 1657-1669.

Eickmeyer, S. M., Gamble, G. L., Shahpar, S., \& Do, K. D. (2012). The role and efficacy of exercise in persons with cancer. $P M \& R, 4(11), 874-881$.

Goldhammer, E., Tanchilevitch, A., Maor, I., Beniamini, Y., Rosenschein, U., \& Sagiv, M. (2005). Exercise training modulates cytokines activity in coronary heart disease patients. International journal of cardiology, 100(1), 93-99.

Green, A., Rumberger, J. M., Stuart, C. A., \& Ruhoff, M. S. (2004). Stimulation of lipolysis by tumor necrosis factor$\alpha$ in 3T3-L1 adipocytes is glucose dependent: Implications for long-term regulation of lipolysis. Diabetes, 53(1), 74-81. 
Gutch, M., Kumar, S., Razi, S. M., Gupta, K. K., \& Gupta, A. (2015). Assessment of insulin sensitivity/resistance. Indian journal of endocrinology and metabolism, 19(1), 160.

Halson, S. L., Lancaster, G. I., Jeukendrup, A. E., \& Gleeson, M. (2003). Immunological responses to overreaching in cyclists. Medicine \& Science in Sports \& Exercise, 35(5), 854-861.

Hollander, J., Fiebig, R., Gore, M., Ookawara, T., Ohno, H., \& Ji, L. (2001). Superoxide dismutase gene expression is activated by a single bout of exercise in rat skeletal muscle. Pflügers Archiv, 442(3), 426-434.

Hotamisligil, G. S., Peraldi, P., Budavari, A., Ellis, R., White, M. F., \& Spiegelman, B. M. (1996). IRS-1-mediated inhibition of insulin receptor tyrosine kinase activity in TNF- $\alpha$-and obesity-induced insulin resistance. Science, 271(5249), 665-670.

Jung, S. H., Park, H. S., Kim, K. S., Choi, W. H., Ahn, C. W., Kim, B. T., ... \& Lee, K. W. (2008). Effect of weight loss on some serum cytokines in human obesity: increase in IL-10 after weight loss. The Journal of nutritional biochemistry, 19(6), 371-375.

Kharraz, Y., Guerra, J., Mann, C. J., Serrano, A. L., \& Muñoz-Cánoves, P. (2013). Macrophage plasticity and the role of inflammation in skeletal muscle repair. Mediators of inflammation, 2013.

Kramer, H. F., \& Goodyear, L. J. (2007). Exercise, MAPK, and NF-кB signaling in skeletal muscle. Journal of applied physiology, 103(1), 388-395.

Kumar, S. A., Maiya, A. G., Shastry, B. A., Vaishali, K., Ravishankar, N., Hazari, A., ... \& Jadhav, R. (2018). Exercise and insulin resistance in type 2 diabetes mellitus: A systematic review and meta-analysis. Annals of Physical and Rehabilitation Medicine, 62(1), 1-6.

Leggate, M., Carter, W. G., Evans, M. J., Vennard, R. A., Sribala-Sundaram, S., \& Nimmo, M. A. (2012). Determination of inflammatory and prominent proteomic changes in plasma and adipose tissue after high-intensity intermittent training in overweight and obese males. Journal of Applied Physiology, 112(8), 1353-1360.

Lloyd, J. W., Evans, K. A., Zerfass, K. M., Holmstrup, M. E., Kanaley, J. A., \& Keslacy, S. (2016). Effect of an acute bout of aerobic exercise on chemerin levels in obese adults. Diabetes \& Metabolic Syndrome: Clinical Research \& Reviews, 10(1), 37-42.

Merawati, D., Kinanti, R. G., Susanto, H., \& Taufiq, A. (2018, September). The attenuation of physicalphysiological stresses through musical-high intensity exercise co-treatment in non-athlete individual. In Journal of Physics: Conference Series (Vol. 1093, No. 1, p. 012026). IOP Publishing.

Moldoveanu, A. I., Shephard, R. J., \& Shek, P. N. (2001). The cytokine response to physical activity and training. Sports medicine, 31(2), 115-144.

Monzillo, L. U., Hamdy, O., Horton, E. S., Ledbury, S., Mullooly, C., Jarema, C., ... \& Mantzoros, C. S. (2003). Effect of lifestyle modification on adipokine levels in obese subjects with insulin resistance. Obesity research, 11(9), 1048-1054.

Niess, A. M., \& Simon, P. (2007). Response and adaptation of skeletal muscle to exercise-the role of reactive oxygen species. Front Biosci, 12(12), 4826-38.

Park, S. E., Rhee, E. J., Park, C. Y., Oh, K. W., Park, S. W., Kim, S. W., \& Lee, W. Y. (2013). Impact of hyperinsulinemia on the development of hypertension in normotensive, nondiabetic adults: a 4-year follow-up study. Metabolism, 62(4), 532-538.

Petersen, A. M. W., \& Pedersen, B. K. (2005). The anti-inflammatory effect of exercise. Journal of applied physiology, 98(4), 1154-1162.

Powers, S. K., Howley, E. T., \& Quindry, J. (2007). Exercise physiology: Theory and application to fitness and performance (p. 640). New York, NY: McGraw-Hill.

Proske, U., \& Allen, T. J. (2005). Damage to skeletal muscle from eccentric exercise. Exercise and sport sciences reviews, 33(2), 98-104.

Proske, U., \& Morgan, D. L. (2001). Muscle damage from eccentric exercise: mechanism, mechanical signs, adaptation and clinical applications. The Journal of physiology, 537(2), 333-345.

Riskesdas, (2018). Hasil Utama RISKESDAS 2018, (Online), (www.kesmas.kemkes.go.id > ...PDF Hasil web Riskesdas 2018 - Kesmas Kemkes), diakses 1 Desember 2018.

Schütze, S., Berkovic, D., Tomsing, O., Unger, C., \& Krönke, M. (1991). Tumor necrosis factor induces rapid production of 1'2'diacylglycerol by a phosphatidylcholine-specific phospholipase C. The Journal of experimental medicine, 174(5), 975-988. 
Sjöholm, Å., \& Nyström, T. (2006). Inflammation and the etiology of type 2 diabetes. Diabetes/metabolism research and reviews, 22(1), 4-10.

TaheriChadorneshin, H., Cheragh-Birjandi, S., Goodarzy, S., \& Ahmadabadi, F. (2019). The impact of high intensity interval training on serum chemerin, tumor necrosis factor-alpha and insulin resistance in overweight women. Obesity medicine, 14, 100101

Thyfault, J. P., \& Booth, F. W. (2011). Lack of regular physical exercise or too much inactivity. Current Opinion in Clinical Nutrition \& Metabolic Care, 14(4), 374-378.

Usui, T., Yoshikawa, T., Ueda, S. Y., Katsura, Y., Orita, K., \& Fujimoto, S. (2011). Effects of acute prolonged strenuous exercise on the salivary stress markers and inflammatory cytokines. Japanese Journal of Physical Fitness and Sports Medicine, 60(3), 295-304.

Wretman, C., Lionikas, A., Widegren, U., Lännergren, J., Westerblad, H., \& Henriksson, J. (2001). Effects of concentric and eccentric contractions on phosphorylation of MAPKerk1/2 and MAPKp38 in isolated rat skeletal muscle. The Journal of physiology, 535(1), 155-164.

Yamasaki, A., Booker, A., Kapur, V., Tilt, A., Niess, H., Lillemoe, K. D., ... \& Conrad, C. (2012). The impact of music on metabolism. Nutrition, 28(11-12), 1075-1080.

Yu, C., Chen, Y., Cline, G. W., Zhang, D., Zong, H., Wang, Y., ... \& Shulman, G. I. (2002). Mechanism by which fatty acids inhibit insulin activation of insulin receptor substrate-1 (IRS-1)-associated phosphatidylinositol 3-kinase activity in muscle. Journal of Biological Chemistry, 277(52), 50230-50236 